\title{
PENDAMPINGAN PADA USAHA MAKRO KECIL MENENGAH (UMKM) UNTUK MENINGKATKAN DAYA SAING MELALUI PENINGKATAN PRODUKTIVITAS
}

\author{
${ }^{1 *}$ Iman Karyadi, ${ }^{2}$ Indahwati, ${ }^{3}$ Dijah Julindrastuti \\ Universitas Wijaya Kusuma, Surabaya, Indonesia \\ Email : *imankaryadi@uwks.ac.id
}

Manuskrip: Juni -2021; Ditinjau: Juni -2021; Diterima: Juli -2021; Online: Juli-2021; Diterbitkan: Juli-2021

\begin{abstract}
ABSTRAK
Daya saing Propinsi JawaTimur berada di urutan ke sepuluh denga index produktivittas sebesar 19,56, (laporan analisis daya saing UMKM di Indonesia, www.google.com). Rendahnya daya saing propinsi Jawa Timur terkait dengan masalah hambatan UMKM mengakses sumber daya produktif, selain pendanaan, terutama masalah akses bahan baku, pembiayaan, tenaga kerja trampil dan teknologi, di samping itu juga permasalahan kapasitas pengolahan dan persaingan.Tujuan pengabdian kepada masyarakat ini adalah agar Usaha Mikro kecil menengah (UMKM) dapat melakukan manajemen dengan lebih baik. Peningkatan produktivitas diperlukan untuk bisa meningkatkan daya saing..Pelaksanaan pendampingan UMKM ini direncanakan di Asosiasi Usaha Kecil Menengah Amangtiwi yang berlokasi di Sawojajar Malang. Pengabdian kepada Masyarakat ini diawali dengan memberikan pemaparan materi mengenai produktivitas dan daya saing. Selanjutnya akan dilakukan pendalaman mengenai kekuatan, kelemahan, peluang dan ancaman bagi UMKM, hal ini dimaksudkan agar bisa memadukan secara langsung teori dengan kondisi di lapangan. Dengan demikian dapat diambil kesimpulan dan solusi terbaik bagi UMKM dalam menjalankan bisnisnya agar dapat berdaya saing.
\end{abstract}

\section{Kata Kunci: UMKM, Daya Saing Dan Produktivitas}

\section{PENDAHULUAN}

Daya saing Propinsi Jawa Timur berada di urutan ke sepuluh dengan index produktivitas sebesar 19,56, sementara yang tertinggi adalah Jakarta (laporan analisis daya saing UMKM di Indonesia, www.google.com). Ini menunjukkan bahwa indikator daya saing adalah produktivitas itu sendiri. Rendahnya daya saing propinsi Jawa Timur terkait dengan masalah hambatan UMKM mengakses sumber daya produktif, selain pendanaan, terutama masalah akses bahan baku, pembiayaan, tenaga kerja trampil dan teknologi, di samping itu juga permasalahan kapasitas pengolahan dan persaingan. 
Keberadaan Usaha Mikro kecil menengah (UMKM) berdasarkan UndangUndang No. 20 tahun 2008 merupakan unit usaha ekonomi produktif yang dimiliki seseorang. UMKM mampu bertahan hidup di tengan krisis ekonomi tahun 1998, di mana banyak bisnis besar yang tumbang. Semester pertama tahun 2020 kondisi perekonomian kembali menghadapi situasi sulit karena adanya wabah virus corona COVID 19 yang sangat berdampak sekali pada UMKM dimana bila pada tahun 1998 pada saat krisis ekonomi UMKM mampu bertahan tetapi pada saat ini UMKM sangat merasakan dampak dari wabah virus ini. Kondisi krisis ekonomi tahun 1998 menunjukkan bahwa UMKM mampu menggerakkan perekonomian di Indonesia akan tetapi sangat disayangkan banyak UMKM yang kurang mampu berkembang karena berbagai kendala yang dihadapi. Kalau pada thn 1998 ditengah krisis dan kendala yang dihadapi meski UMKM harus dengan tertatih menjalankan bisnisnya akan tetapi masih mampu untuk bertahan sedangkan pada kondisi Covid ini tidak sedikit UMKM yang harus berhenti usahanya karena dampak dari wabah ini.

Kondisi yang terjadi pada saat ini yang melatar belakangi untuk melakukanPengabdian kepada Masyarakat dengan harapan akan bisa memberikan bekal serta membantu UMKM agar dapat bertahan dengan cara meningkatkan daya saingnya. Peningkatan daya saing tersebut diperlukan agar para pelaku UMKM dapat menilai kinerjanya sendiri melalui peningkatan produktivitasnya.

Pelaksanaan pendampingan untuk meningkatkan daya saing melalui peningkatan produktivitas UMKM ini di Asosiasi Usaha Kecil Menengah Amangtiwi yang berlokasi di Sawojajar Malang. Amangtiwi merupakan singkatan dari Arema Hasta Manghayu Pertiwi artinya buah karya arek Malang yang menghiasi pertiwi. Amangtiwi merupakan paguyuban Usaha Kecil Menengah yang resmi berbadan hukum tanggal 24 februari 2012. Badan Hukum dengan No: 518/4/35.73.112/2012. Usaha anggotanya meliputi: kuliner, fashion, pertokoan, koperasi simpan pinjam dan craft (kerajinan tangan).

Visi Amangtiwi adalah: terwujudnya lembaga ekonomi dan sosial yang tangguh yang mampu memberikan pelayanan prima kepada anggota dalam meningkatkan pendapatan dan kesejahteraan anggota. Misi Amangtiwi: 1) memberikan pelayanan simpan pinjam kepada anggota sebagai mitra kerja, sesuai dengan SOM dan SOP koperasi. 2) Meningkatkan pelayanan kebutuhan pokok anggota. 3) Meningkatkan peran serta anggota dalam pengembangan Koperasi ke arah yang lebih maju dan produktif. 4) Menjalankan kerja sama dengan berbagai pihak untuk meningkatkan pendapatan dan promosi usaha anggota. Tujuan Amangtiwi: 1) Meningkatkan tali persaudaraan dan kebersamaan di antara sesama anggota Koperasi. 2) Memberdayakan kegiatan Koperasi dengan maksimal, efisien, efektif dan produktif dalam meningkatkan kesejahteraan anggotanya. 3) Meningkatkan pendapatan dan kesejahteraan anggota Koperasi.

Kondisi yang terjadi saat ini dengan adanya pandemi covid 19 membuat kondisi UMKM semakin mengalami kesulitan tidak terkecuali untuk UMKM Amangtiwi. Kebijakan yang diambil oleh pemerintah seperti PSBB, PPKM dan sebagainya membuat kondisi semakain sulit.Pembatasan waktu untuk bisa beraktivitas, pengiriman yang tidak lancar, daya beli konsumen yang rendah serta 
sulitnya mendapatkan tambahan modal merupakan hal yang harus dihadapi oleh UMKM.Berlangsungnya hidup UMKM memerlukan adanya usaha yang keras dari para pelaku UMKM ini.

Berbagai upaya harus dilakukan oleh UMKM ditengah kondisi saat ini diantaranya bagaimana bisa meningkatkan produktivitas UMKM.Banyak cara untuk meningkatkan produktivitas diantaranya mereka bisa bergabung dimana hal ini akan bisa memudahkan mereka dalam pemasaran.UMKM yang menghasilkan produk- produk sejenis mereka bisa saling berkolaborasi untuk produknya dan pemasarannya.

\section{METODE PELAKSANAAN KEGIATAN}

Pengabdian kepada Masyarakat ini diawali dengan memberikan pemaparan materi mengenai produktivitas dan daya saing. Untuk memberikan pemahaman tentang perlunya produktivitas, sehingga para pelaku UMKM dapat menggali permasalahan terkait dengan peningkatan produktivitas. Selanjutnya akan dilakukan pendalaman mengenai kekuatan, kelemahan, peluang dan ancaman bagi UMKM, hal ini dimaksudkan agar bisa memadukan secara langsung teori dengan kondisi di lapangan. Dengan demikian dapat diambil kesimpulan dan solusi terbaik bagi UMKM dalam menjalankan bisnisnya agar dapat berdaya saing.

\section{KERANGKA PEMIKIRAN}

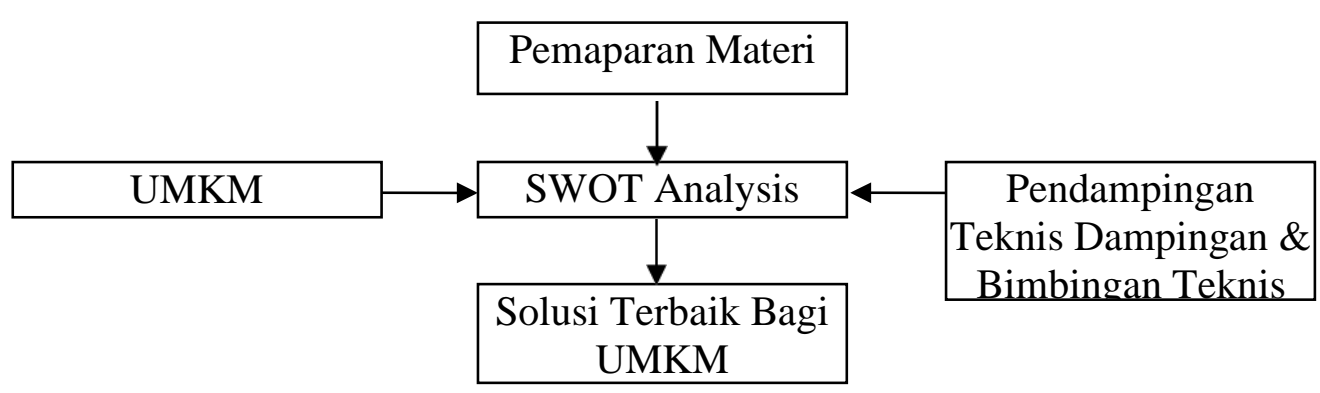

Gambar 1. Kerangka Pemikiran

Pendampingan dimulai dari pemberian materi tentang produktivitas dan daya saing. Adapun materi yang disampaikan dalam penyuluhan meliputi Definisi Produktivitas,Ukuran Produktivitas, Cara meningkatkan produktivitas, Definisi Daya Saing dan Bagaimana Produktivitas akan mampu membantu dalam menghadapi persaingan UMKM . Setelah kegiatan penyuluhan dilanjutkan dengan melakukan pendampingan. 


\section{PENGABDIAN MASYARAKAT}

PENDAMPINGAN PADA USAHA MIKRO KECIL. DAN MENENGAH ( UMKM ) UNTUK MENINGKATKAN DAYA SAING MEL.AL.UI PENINGKATAN PRODUKTTVITAS

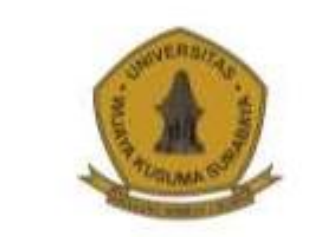

OLEH:

EAKULTAS FKONOMI DAN BISNIS

UNIVERSTTAS WUAYA KUSUMA SUMABAYA

- Des. Ec. Iman Karyadil, MM, Ak, CA

- Dr. Indahwati, SE, MM

- Dijah julindrastuti, SE, M.Ak.

\section{PERMASALAHAN MENDASAR UMKM}

Dianggap sebagai usaha sampingan

Konsep Manajerial yang lemah

Permodalan

Tidak adanya Pemisahan Kekayaan

(Konsep Entitas)

Tidak Dilakukan Pencatatan

\section{Latar Belakang}

- Rendahnya daya saing UMKM yang diukur dengan produktivitas di mana Jawa Timur di urutan ke 10 dengan index 19,56.

- Keberadaan UMKM yang mampu bertahan hidup di tengah krisis ekonomi tahun 1998 , sementara banyak bisnis besar yang tumbang

- Saat ini dunia mengalami krisis karena adanya wabah COVID 19

- UMKM perlu berbenah dalam upaya untuk fefap Bertahan hidup dengan meningkatkan daya saingnya dan meningkatkan produktivitas nya

Gambar 2. Materi Pendampingan 


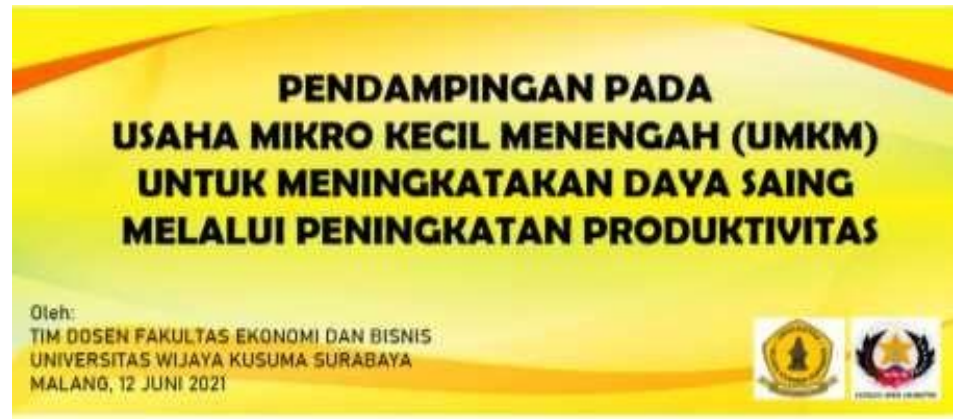

Gambar 3. Banner Pendampingan

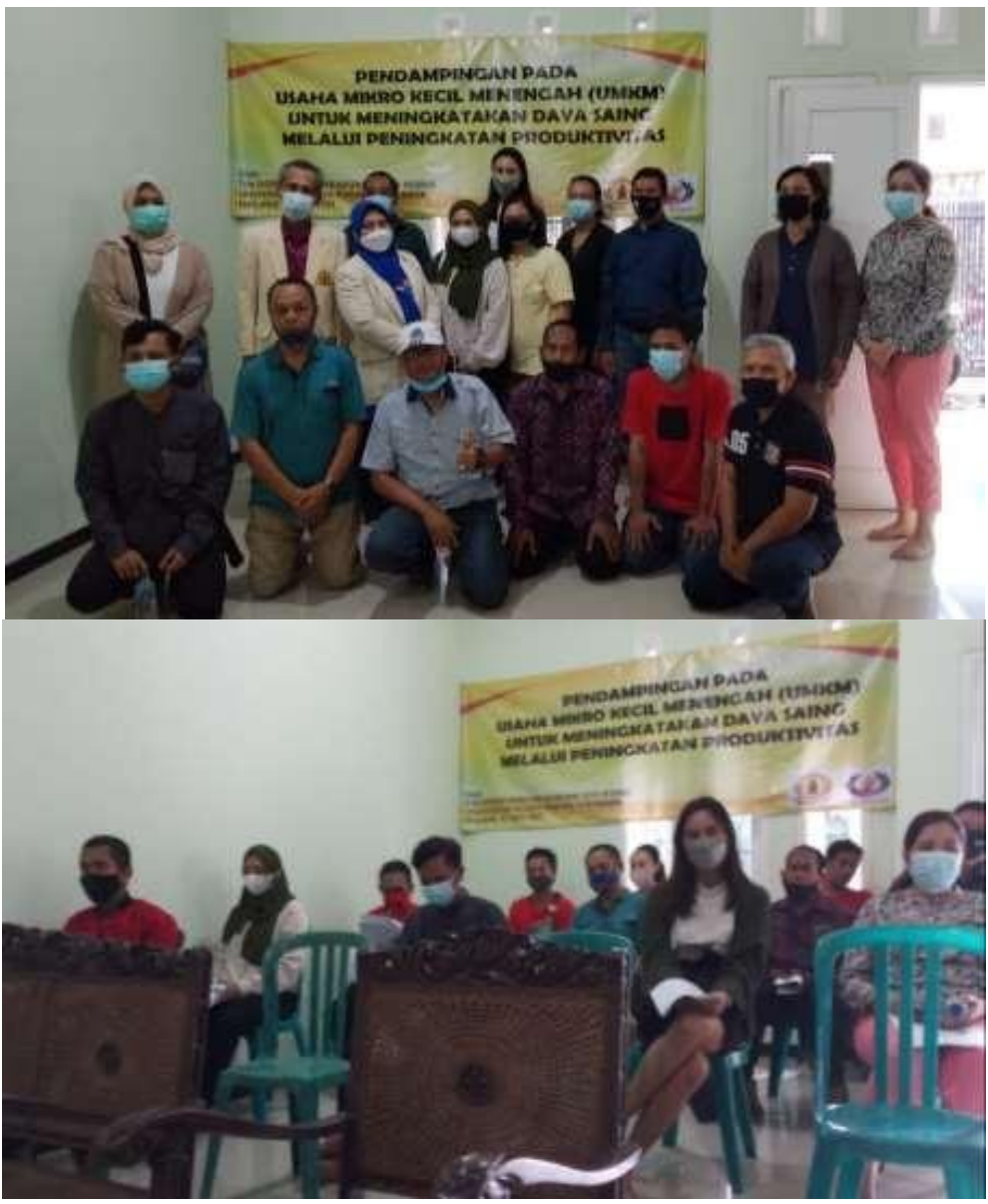

Gambar 4. Pelaksanaan Pendampingan

\section{HASIL DAN PEMBAHASAN}

Pelaksanaan Kegiatan Pengabdian Kepada Masyarakat ini, berlangsung untuk semester Genapl Tahun Akademik 2020- 2021 diawali dengan melakukan survey Pendahuluan sekitar bulan November 2020 ke Asosiasi Usaha Mikro Kecil dan Menengah yang beralamat di Jl. Kapi Minda Raya 10 No, 24 Sawojajar Kotamadya Malang. 
Kegiatan pengabdian masyarakat ini dilakukan dengan Survey pendahuluan dimana tujuannya adalah untuk memperoleh informasi pendahuluan tentang Permasalahan mendasar pada saat ini dan untuk melalakukakan pemetaan serta alternatif solusi didalam mengatasi permasalahan yang ada apalagi dengan adanya Pandemi Covid 19 saat ini yang sudah mewabah di Indonesia sejak Awal tahun 2020.

Pendampingan Kegiatan Pengabdian Kepada Masyarakat dimulai dari pemberian materi untuk memberikan pemahaman tentang Prinsip Kesinambungan Usaha ( Going Concern Concept ),pemahaman Tentang Arti Pentingnya Produktivitas.melalui produk-produk yang dihasilkan oleh Usaha Mikro Kecil Menegah yang bergabung dalam Asosiasi UMKM Amangtiwi. Sawojajar Malang dan pemahaman tentang Daya Saing dalam Upaya mempertahankan dan meningkatkan keberlangsungan Usaha. Anggota UMKM Amangtiwi Malang.

Hasil dari kegiatan pengabdian masyarakat ini para pelaku UMKM Amangtiwi adalah mereka mendapatkan gambaran bagaimana bisa bertahan di tengan kondisi yang terjadi saat ini melalui peningkatan produktivitas. Kegiatan pengabdian masyarakat yang dilakukakn ini adalah berupa kegiatan pendampingan yang mana setelah dilakukan penyuluhan adalah melakukan pendampingan pada UMKM Amangtiwi untuk langsung melakukan aktivitas peningkatan produktivitas

Peningkatan produktivitas yang dilakukan adalah untuk usaha-usaha yang sejenis mereka bergabung menjadi satu yaitu untuk usaha makanan jenis kripik mereka bergabung jadi satu dan untuk usaha bumbu-bumbu juga mereka menjadi satu.Dari penggabungan ini dari daerah pemasaran yang semula terbatas menjadi berkembang, sebagai contoh UMKM kripik tempe akhirnya bisa masuk ke daerah pemasaran untukmkripik pisang.

Kegiatan pengabdian masyarakat ini dilakukan untuk memberikan semangat kepada UMKM Amangtiwi untuk tetap bertahan di tengan kondisi pandemi ini. Saling bekerjasama dalam produksi produknya dan daerah pemasarannya akan membuat mereka bisa saling membantu.

Capaian dalam kegiatan ini sangat baik karena pada akhirnya mereka mau bergabung baik untuk produk dan daerah pemasarannya dan bahkan mereka mengharapkan untuk bisa membantu mereka dalam merintis pendirian koperasi yang akan bisa membantu para UMKM yang berada dibawah naungan UMKM Amangtiwi.

\section{KESIMPULAN DAN SARAN \\ Kesimpulan}

Kegiatan Pengabdian Kepada Masyarakat yang berupa Pendampingan "Peningkatan Produktivitas dalam Upaya Meningkatkan Daya Saing Pada Usaha Mikro Kecil Dan Menengah ( UMKM ) Amangtiwi "Sawojajar Kotamadya Malang dapat disimpulkan sebagai berikut :Perlunya satu pemahaman dan Focus terhadap Visi dan Misi Perusahaan dengan mengembangkan rencana bisnis yang solid dalam rangka pencapaian produktivitas misalnya dengan meakukan Komunikasi yang efektif yang akan memudahkan untuk kolaborasi dalam produk 
dan daerah pemasaran, perlunya pengembangan Kreativitas dan Inovasi yang tinggi serta berlelanjutan, Penggunaan Metode dan Strategi yang tepat dalam program pemasaran produk-produk yang dihasilkan.

\section{Saran}

Untuk bisa tetap bertahan dalam kondisi saat ini dan untuk kemajuan yang akan datang maka perlu dilakukan efisien biaya, misalnya pada Pengelolaan Biaya Produksi dan Operasi, perlunya dilakukan Quality Control secara Intensive, sehngga dapat mengurangi Produk-produk cacat/ rusak, sehingga Daya saing perusahaan dapat ditingkatkan dan perlunya dilakukan Penggabungan Usaha bagi Anggota UMKM yng memilik usaha yang Sejenis.

\section{DAFTAR PUSTAKA}

Ajimat, A., et al. (2020). Berwirausaha Memanfaatkan Media Sosial Pada Daerah Sepatan. ADI Pengabdian Kepada Masyarakat, 1(1), 69-76.

Arti produktivitas: Memahami apa itu produktivitas dan factor yang mempengaruhinya, www.maxmanroe.com

Hadi, Gamal, 2017, Apakah yang dimaksud dengan daya saing atau heightened competition?, dictio PKL Online, www.dictio.id

Kho, Budi, 2019, Pengetahuan tentang manajemen produksi dan operasional, manajemen SDM dan manajemen kualitas, www.ilmumanajemenindustri.com

Laporan analisis daya saing UMKM di Indonesia, www.google.com

Putra, IGS., Nababan, D., Ligar, AH., (2020). Dampak Pelatihan Manajemen Kreatif Industri Peci Menuju Sentra Peci Di Desa Langonsari Kecamatan Pameungpeuk Kabupaten Bandung. Coopetition:Jurnal Ilmiah Manajemen. 11(1). 